\title{
Prevalence and factors associated with tea consumption in the first month of life in a birth cohort in the Northeast Region of Brazil
}

Rosana Porto Cirqueira 1

https://orcid.org/0000-0002-4319-6037

Taiane Gonçalves Novaes 2

https://orcid.org/ 0000-0002-9180-5490

Andressa Tavares Gomes 3

https://orcid.org/0000-0002-5366-2804

Vanessa Moraes Bezerra 4

(D) https://orcid.org/0000-0001-5333-2875

\author{
Michele Pereira Netto 5 \\ iD https://orcid.org/ 0000-0003-0017-6578 \\ Daniela da Silva Rocha 6 \\ iD https://orcid.org/0000-0001-6969-6841
}

1,3,4,6 Instituto Multidisciplinar em Saúde. Universidade Federal da Bahia. Campus Anísio Teixeira. Vitória da Conquista, BA, Brasil. E-mail: drochaufba@gmail.com
2 Faculdade de Tecnologia e Ciências. Jequié, BA, Brasil.

5 Departamento de Nutrição. Universidade Federal de Juiz de Fora. Juiz de Fora, MG, Brasil.

\begin{abstract}
Objectives: to determine the prevalence and analyze the factors associated with newborns drinking tea in a birth cohort.

Methods: A cross-sectional study with nested prospective cohort was conduct with 329 puerperal women and their newborns in Vitória da Conquista, Bahia. Sociodemographic and information about the newborn's diet and mothers/babies was obtained at a maternity and 30 days after birth, at home visits. The prevalence ratios $(P R)$ and its respective confidence intervals (CI95\%) were estimated with Poisson regression models according to the hierarchical conceptual model.

Results: the prevalence of tea consumption up to 30 days of life was $34.6 \%(C 195 \%=29.7$; $40.0 \%)$. The sociodemographic and maternal characteristics associated with the outcome were not having a partner $(P R=1.39 ; C 195 \%=1.03-1.88)$, more than eight years of schooling $(P R=1.38 ; C 195 \%=1.03-1.84)$, lower income $(P R=2.21 ; C I 95 \%=1.31-3.73)$, primiparous $(P R=1.48 ; C 195 \%=1.01-2.17)$ and does not have any experience with breastfeeding before $(P R=2.25 ; C I 95 \%=1.48-3.41)$. As for the child, there was a higher prevalence of tea consumption than among those who received artificial milk in the first month of life $(P R=2.10 ; C 195 \%=1.62-2.73)$.

Conclusions: the offer of tea in the first month of life was high. Tea consumption was positively associated with sociodemographic, maternal and newborn feeding factors.
\end{abstract}

Key words Herbal tea, Newborn, Infant nutrition, Artificial feeding

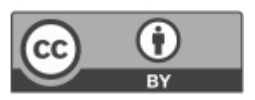




\section{Introduction}

An early introduction of non-nutritious fluids, such as tea, in children's diet younger than six months is considered inadequate and harmful to their health, it is a cultural practice widely spread among the Brazilian population..$^{1-3}$ The prevalence of this practice ranges from $16.2 \%$ to $68.8 \%$ in the first month of children's lives. ${ }^{4-7}$

Giving tea to babies can increase the risk of food poisoning, since plants synthesize secondary metabolites as a defense mechanism when they interact with other plants and these naturally produced substances can have toxic/mutagenic potential. 8 These fluids can also be contaminated with enteropathogens, whose intake is associated with a higher risk of morbidity and mortality in the first six months of children's lives. ${ }^{9}$

Besides lacking important nutrients for children's development and growth in its composition, different types of tea often provided to them present substances capable of compromising the bioavailability of different breast milk-related minerals. 10 Giving tea to babies can lead in reducing their appetite and breast suction, a fact that may decrease mothers' milk production and interrupt breastfeeding. 11

Factors such as low maternal schooling, young mothers, pacifier and bottle, and shorter exclusive breastfeeding time have been associated with the early introduction of tea, or of other fluids such as water and/or fruit juice, in children's diet younger than one year old. $3,12-15$

Despite the high prevalence, and consequences, of tea consumption, national studies about factors associated with tea introduction in babies' diet remain scarce.3,12 Understanding these factors is of paramount importance to help reduce tea consumption in order to avoid complications in children's health. This study analyzed the prevalence and factors associated with tea consumption in newborns' diet, in a birth cohort study carried out in Vitoria da Conquista-BA, an important urban center in the Northeast region in Brazil.

\section{Methods}

A sectional study nested in a prospective birth cohort research carried out in Vitória da Conquista - BA, which is the third largest countryside in the State and the fifth largest countryside in the Brazilian Northeast region - its population in 2020 comprises 341,128 inhabitants. 16

Mothers who participated in this cohort study were recruited within 24 hours after childbirth, from all the maternity hospitals that provided public and/or private assistance in the countryside and they were followed-up through home visits conducted from February 2017 to October 2018. Eligibility criteria comprised puerperal women living in the urban area of the countryside, who delivered nontwin children and at term. Children born from HIVpositive mothers and children presenting malformations capable of compromising breastfeeding were excluded from the study.

Information about sociodemographic conditions, other maternal features, prenatal care and childbirth were collected based on a questionnaire applied to mothers at the time they stayed at the maternity hospitals.

Children were followed-up through home visits carried out at 30,180 and 365 days after childbirth in order to collect information about the children (care provided to the child, breastfeeding, complementary feeding introduction, pacifier and bottle using, and the child's health conditions). Some children were visited later than scheduled due to mothers' availability for the interview.

In this current study, data were collected at the maternity and the babies' 30th day of life, from February to November 2017. Interviews were conducted by trained researchers in order to standardize data collection procedures and to avoid errors in the collected information.

The sample size was calculated (a posteriori) based on the following parameters: prevalence on tea consumption was $16.2 \%$ in children younger than 30 days old and lived in the Brazilian Northeast region, ${ }^{6}$ odds ratio of $1.6,80 \%$ power and $95 \%$ confidence level - minimum sample size comprised 275 binomial mothers/babies.

Mothers' report about any tea intake by children in their first 30 days of life ("Has the baby had tea yet?") was the dependent variable. Information about children's age at the time tea was first consumed, daily tea intake, the reason why tea was offered and whether mothers were instructed by someone to offer children tea were also collected.

Independent variables were selected based on studies about the topic; they were arranged in three blocks, based on hierarchical conceptual model, namely: distal block (sociodemographic and maternal characteristics), intermediate block (variables related to prenatal and maternal care) and proximal block (variables related to the child and maternal breastfeeding) [Figure 1].

Independent variables belonging to the distal block were: maternal age (categorized as $\geq 20$ years 
old and $<20$ years old); maternal skin color (white and non-white); maternal marital status (with a partner - married, cohabiting; and without a partner single, divorced, widow); maternal schooling ( $>8$ years and $\leq 8$ years of schooling); economic classification based on the criterion suggested by the Associação Brasileira de Empresas de Pesquisa (ABEP) ${ }^{17}$ (Brazilian Association of Research), categorized in classes A, B and in classes C, D, E (women classified in the last category were assumed to have low income); number of children (multiparous and primiparous) and previous breastfeeding experience (yes / no).

Variables belonging to the intermediate block were categorized as follows: number of prenatal consultations $(\geq 6$ consultations and $<6$ consultations); participation in pregnancy support group (yes/no); instructions about breastfeeding during prenatal care (yes/no); type of delivery (vaginal and cesarean section) and the use of bottle at the hospital (yes/no).

Variables belonging to the proximal block comprised birth weight $(\geq 2,500 \mathrm{~g}$ and $<2,500 \mathrm{~g})$; type of feeding in the babies first month of life (breastfeeding; artificial milk); breast issues and the use of pacifier in the babies first month of life (yes/no).

Statistical analyzes were carried out on Stata software, version 14.0. The frequency of distribution on the characteristics of the population such as sociodemographic, obstetric and neonatal factors were described in the current study.

Gross and adjusted associations between predictor variables and outcome were analyzed through robust-variance Poisson regression, whereas effect magnitude was estimated by calculating the gross/adjusted prevalence ratio (PR). Gross prevalence ratios of investigated factors-event association were initially estimated. Next, multivariate regression analysis was performed based on the proposed hierarchical conceptual model. Variables associated with the event at significance level of $p \leq 0.20$, in the bivariate analysis, were included in multiple regression models.

Variables belonging to each block and to hierarchically superior blocks were adjusted through variables belonging to the following block. Variables presenting significance level of $p \leq 0.05$ remained in the final model, in their respective adjustment block, regardless of whether, or not, they lost statistical significance in the following block.

The current research met the ethical aspects of

Figure 1

Conceptual hierarchical model of factors associated with tea introduction in babies' diet in their first 30 days of life.

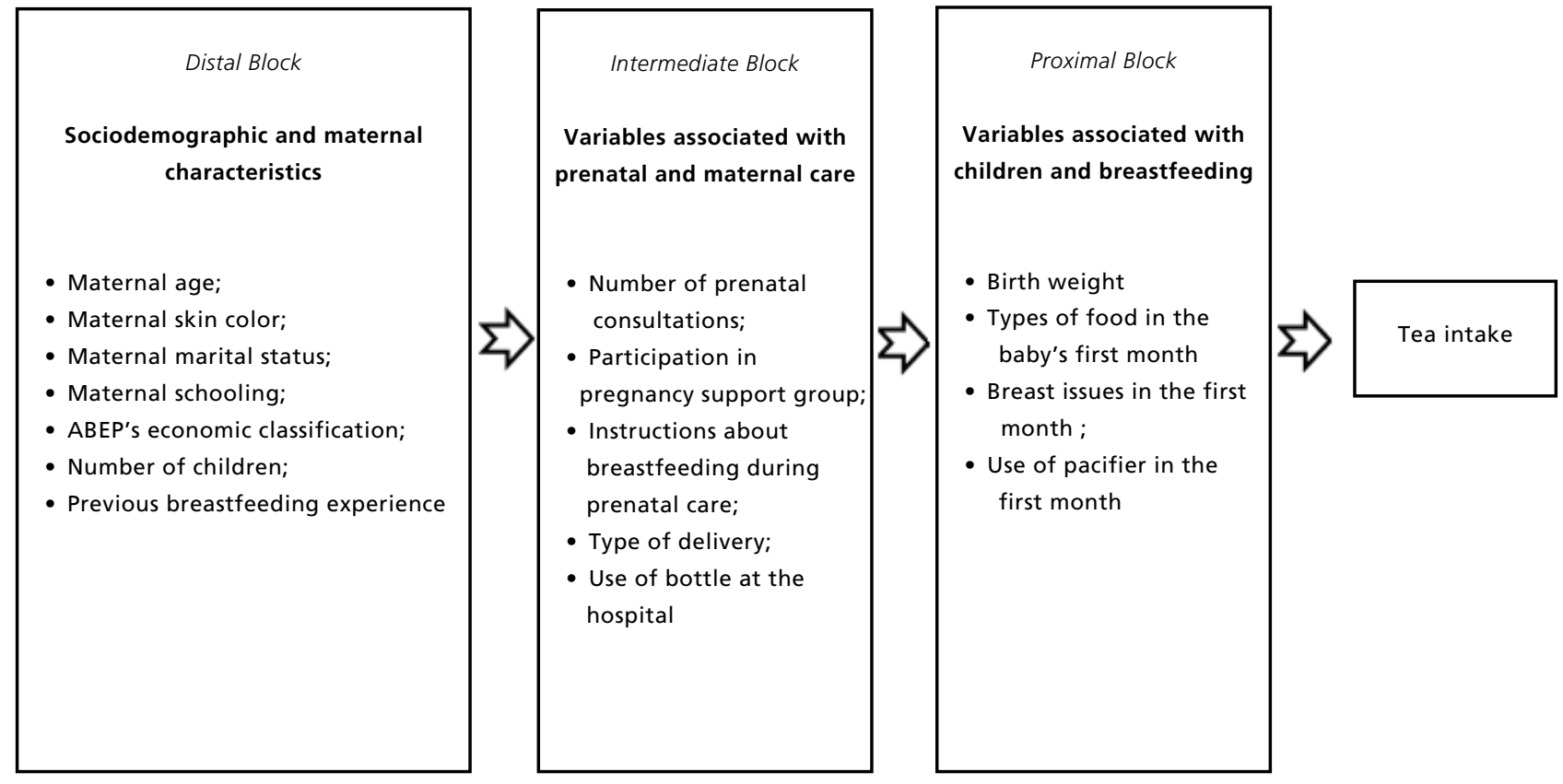

$\mathrm{ABEP}=$ Associação Brasileira de Empresa de Pesquisa (Brazilian Association of Research). 
studies involving human beings, which are ruled by the Conselho Nacional de Saúde (CNS) (National Health Council) resolution n. 466/12. In addition, it was approved by the Research Ethics Committee at Universidade Federal da Bahia / Instituto Multidisciplinar em Saúde (UFBA/IMS), under the protocol number 1.861.163. Data collection took place by puerperal women who signed the Informed Consent Form (ICF).

\section{Results}

The initial cohort comprised 388 mother-baby pairs. Follow-up loss reached $15.2 \% \quad(n=59)$, which resulted in the total number of 329 puerperal women and their newborns - who were examined at the first scheduled visit (30 days after childbirth). The aforementioned loss resulted in the impossibility of making contact with mothers' over the phone, wrong address and mothers' change of address to other cities or to the rural area of the countryside.

As for the mothers' characteristics, most of them were non-white $(75.7 \%), 20$ years old or older (87.8\%), belonged to lower economic class $(72.3 \%)$ and had a partner $(77.8 \%)$. The lack of previous breastfeeding experience was reported by $54.7 \%$ of interviewees (Table 1).

Information shown in Table 2 refers to characteristics associated with prenatal and maternal care. $80.6 \%$ of the puerperal women attended six or more prenatal consultations, $70.0 \%$ received instructions about breastfeeding during these consultations and $73.2 \%$ did not participate in pregnancy support groups. Cesarean section $(53.5 \%)$ was the most frequent type of delivery; $91.7 \%$ of the babies did not use a bottle at the maternity hospital.

In relation to newborns, $50.8 \%$ were boys, mean birth weight was 3,215.6 \pm 413.0 grams and $4.3 \%$ of the babies presented low birthweight. Most children were breastfed (73.6\%) and used pacifier (51.1\%). In addition, $55.0 \%$ of the mothers reported not having breast issues (Table 3 ).

Tea consumption by babies in their first 30 days of life presented a prevalence of $34.6 \%$ $(\mathrm{CI} 95 \%=29.7 \% ; 40.0 \%)$; the mean age of the babies at the time tea was introduced to them was $18.9 \pm 8.3$ days. Most mothers reported giving tea was recommended by a family member $(61.4 \%)$ their own decision in giving their babies tea $(26.3 \%)$, and $12.3 \%$ was due to the physician or by other health professionals' recommendation. The reasons reported by mothers for giving their babies tea were incidence of colic and gas $(74.6 \%)$, constipation $(7.0 \%)$, to calm their child (4.4\%), among other reasons (14\%) such as a cold, jaundice, reflux, lack of milk and for a matter of habit. In relation to the daily frequency of giving tea to babies, most mothers reported doing it once a day $(78.1 \%), 14 \%$ did it twice a day and $7.9 \%$, three, or more, times a day.

Based on the univariate analysis, all variables in the distal block - except for maternal age and skin color - were associated with tea consumption (Table 1). In relation to the variables in the intermediate block, "number of prenatal consultations" and "participation in pregnancy support group" were included in the multivariate model (Table 2). As for the proximal block, variables "types of feeding baby" and "the use of pacifier" in the first 30 days of a baby's life were included in the model (Table 3 ).

Based on the multivariate analysis, lower maternal schooling $(\mathrm{PR}=1.38$; CI95\% $=1.03-1.84)$, mothers without a partner $(\mathrm{PR}=1.39$; $\mathrm{CI} 95 \%=1.03$ $1.88)$, lower economic class level $(\mathrm{PR}=2.21$; $\mathrm{CI} 95 \%=1.31-3.73)$, primiparous mothers $(\mathrm{PR}=1.48$; $\mathrm{CI} 95 \%=1.01-2.17)$ with no previous breastfeeding experience $(\mathrm{PR}=2.25$; $\mathrm{CI} 95 \%=1.48-3.41)$ and children used a bottle in their first 30 days of life $(\mathrm{PR}=2.10$; $\mathrm{CI} 95 \%=1.62-2.73)$ all remained positively associated with the outcomes in the study. No intermediate level variable remained significant in its respective block (Table 4).

\section{Discussion}

Approximately one third of the study population consumed tea in their first month of life. This prevalence was even higher in children born from mothers' who had low-income and schooling, did not have a partner, who were primiparous and did not have breastfeeding experience. In addition, children who used artificial milk presented a higher tea consumption.

The prevalence of tea consumption in the children's first month of life has exceeded the prevalence observed in the II Pesquisa de Prevalência do Aleitamento Materno nas Capitais Brasileiras e Distrito Federal (34.6\% vs. 15.3\%).6 (II Survey about Breastfeeding Prevalence in Brazilian Capitals). However, studies carried out in Goiânia and Viçosa cities have found prevalence of tea consumption similar to the present study: $32.6 \% 18$ and $36.8 \%,{ }^{19}$ respectively.

Most mothers in the present study reported the incidence of colic and gas in their children as the reason to give tea. The early introduction of tea in Brazilian children's diet can be explained by the belief in its medicinal functions, namely4: mitigating infantile colic 5,18 and earache, preventing and 
Table 1

Gross prevalence and prevalence ratio (PR) of tea consumption in the babies' first month of life, according to sociodemographic and maternal characteristics. Vitória da Conquista, BA, Brazil, 2017. ( $n=329)$.

\begin{tabular}{|c|c|c|c|c|c|c|}
\hline Variables & $\mathbf{N}$ & $\%$ & $\begin{array}{l}\text { Prevalence of tea } \\
\text { consumption (\%) }\end{array}$ & $\begin{array}{c}\text { PRa } \\
\text { (gross) }\end{array}$ & $\mathrm{Cl} 95 \% \mathrm{~b}$ & $p$ \\
\hline \multicolumn{7}{|l|}{ Maternal age (years) } \\
\hline$\geq 20$ & 289 & 87.8 & 33.56 & 1 & & \\
\hline$<20$ & 40 & 12.2 & 42.50 & 1.27 & $0.85-1.88$ & 0.243 \\
\hline \multicolumn{7}{|l|}{ Maternal skin color } \\
\hline White & 80 & 24.3 & 30.00 & 1 & & \\
\hline Non-white & 249 & 75.7 & 36.14 & 1.20 & $0.83-1.75$ & 0.329 \\
\hline \multicolumn{7}{|c|}{ Maternal marital status } \\
\hline With a partner & 256 & 77.8 & 30.08 & 1 & & \\
\hline Without a partner & 73 & 22.2 & 50.68 & 1.69 & $1.26-2.26$ & 0.001 \\
\hline \multicolumn{7}{|c|}{ Maternal schooling (years) } \\
\hline$>8$ & 245 & 74.5 & 29.80 & 1 & & \\
\hline$\leq 8$ & 84 & 25.5 & 48.81 & 1.64 & $1.22-2.19$ & 0.001 \\
\hline \multicolumn{7}{|c|}{ Economic classification (ABEP) } \\
\hline Classes A/B & 91 & 27.7 & 15.38 & 1 & & \\
\hline Classes C/D/E & 238 & 72.3 & 42.02 & 2.73 & $1.65-4.53$ & $<0.001$ \\
\hline \multicolumn{7}{|l|}{ Number of children } \\
\hline Multiparous & 169 & 51.4 & 30.77 & 1 & & \\
\hline Primiparous & 160 & 48.6 & 38.75 & 1.26 & $0.93-1.70$ & 0.131 \\
\hline \multicolumn{7}{|c|}{ Previous breastfeeding experience } \\
\hline Yes & 149 & 45.3 & 26.17 & 1 & & \\
\hline No & 180 & 54.7 & 41.67 & 1.59 & $1.16-2.19$ & 0.005 \\
\hline
\end{tabular}

a $\mathrm{PR}=$ prevalence ratio; b $\mathrm{Cl} 95 \%=95 \%$ confidence interval; ABEP = Associação Brasileira de Empresa de Pesquisa (Brazilian Association of Research).

Table 2

Gross prevalence and prevalence ratio (PR) of tea consumption in the babies' first month of life, according to prenatal and childbirth care characteristics. Vitória da Conquista, BA, Brazil, 2017. $(n=329)$

\begin{tabular}{|c|c|c|c|c|c|c|}
\hline Variables & $\mathbf{N}$ & $\%$ & $\begin{array}{l}\text { Prevalence of tea } \\
\text { consumption (\%) }\end{array}$ & $\begin{array}{c}\text { PRa } \\
\text { (gross) }\end{array}$ & $\mathrm{Cl} 95 \% \mathrm{~b}$ & $p$ \\
\hline \multicolumn{7}{|c|}{ Number of prenatal consultations } \\
\hline$\geq 6$ consultations & 265 & 80.6 & 32.45 & 1 & & \\
\hline$<6$ consultations & 64 & 19.4 & 43.75 & 1.35 & $0.97-1.87$ & 0.074 \\
\hline \multicolumn{7}{|c|}{ Participation in pregnancy support group } \\
\hline Yes & 88 & 26.8 & 42.05 & 1 & & \\
\hline No & 240 & 73.2 & 32.08 & 0.76 & $0.56-1.04$ & 0.084 \\
\hline \multicolumn{7}{|c|}{ Instructions about breastfeeding during prenatal care } \\
\hline No & 98 & 30.0 & 30.61 & 1 & & \\
\hline Yes & 229 & 70.0 & 36.68 & 1.20 & $0.85-1.69$ & 0.302 \\
\hline \multicolumn{7}{|l|}{ Type of delivery } \\
\hline Vaginal & 153 & 46.5 & 32.68 & 1 & & \\
\hline Cesarean section & 176 & 53.5 & 36.36 & 1.11 & $0.82-1.50$ & 0.486 \\
\hline \multicolumn{7}{|c|}{ Use of bottle at the hospital } \\
\hline No & 300 & 91.7 & 33.67 & 1 & & \\
\hline Yes & 27 & 8.3 & 44.44 & 1.32 & $0.84-2.07$ & 0.228 \\
\hline
\end{tabular}

a $\mathrm{PR}=$ prevalence ratio; b $\mathrm{Cl} 95 \%=95 \%$ confidence interval. 


\section{Table 3}

Gross prevalence and prevalence ratio (PR) of tea consumption in the babies' first month of life, according to children's and characteristics and maternal breastfeeding. Vitória da Conquista, BA, Brazil, 2017. $(n=329)$

\begin{tabular}{|c|c|c|c|c|c|c|}
\hline Variables & $\mathbf{N}$ & $\%$ & $\begin{array}{l}\text { Prevalence of tea } \\
\text { consumption (\%) }\end{array}$ & $\begin{array}{c}\text { PRa } \\
\text { (gross) }\end{array}$ & $\mathrm{Cl} 95 \% \mathrm{~b}$ & $p$ \\
\hline \multicolumn{7}{|l|}{ Birth weight (g) } \\
\hline$\geq 2.500$ & 315 & 95.7 & 35.24 & 1 & & \\
\hline$<2.500$ & 14 & 4.3 & 21.43 & 0.61 & $0.22-1.68$ & 0.337 \\
\hline \multicolumn{7}{|c|}{ Food type in the baby's first month } \\
\hline Maternal Breastfeeding & 242 & 73.6 & 25.62 & 1 & & \\
\hline Artificial milk & 87 & 26.4 & 59.77 & 2.33 & $1.77-3.07$ & $<0.001$ \\
\hline \multicolumn{7}{|c|}{ Breast issues in the first month } \\
\hline No & 181 & 55.0 & 32.60 & 1 & & \\
\hline Yes & 148 & 45.0 & 37.16 & 1.14 & $0.85-1.53$ & 0.387 \\
\hline \multicolumn{7}{|c|}{ Use of pacifier in the first month } \\
\hline No & 161 & 48.9 & 29.81 & 1 & & \\
\hline Yes & 168 & 51.1 & 39.29 & 1.32 & $0.97-1.78$ & 0.074 \\
\hline
\end{tabular}

a $\mathrm{PR}=$ prevalence ratio; $\mathrm{b} \mathrm{Cl} 95 \%=95 \%$ confidence interval

\section{Table 4}

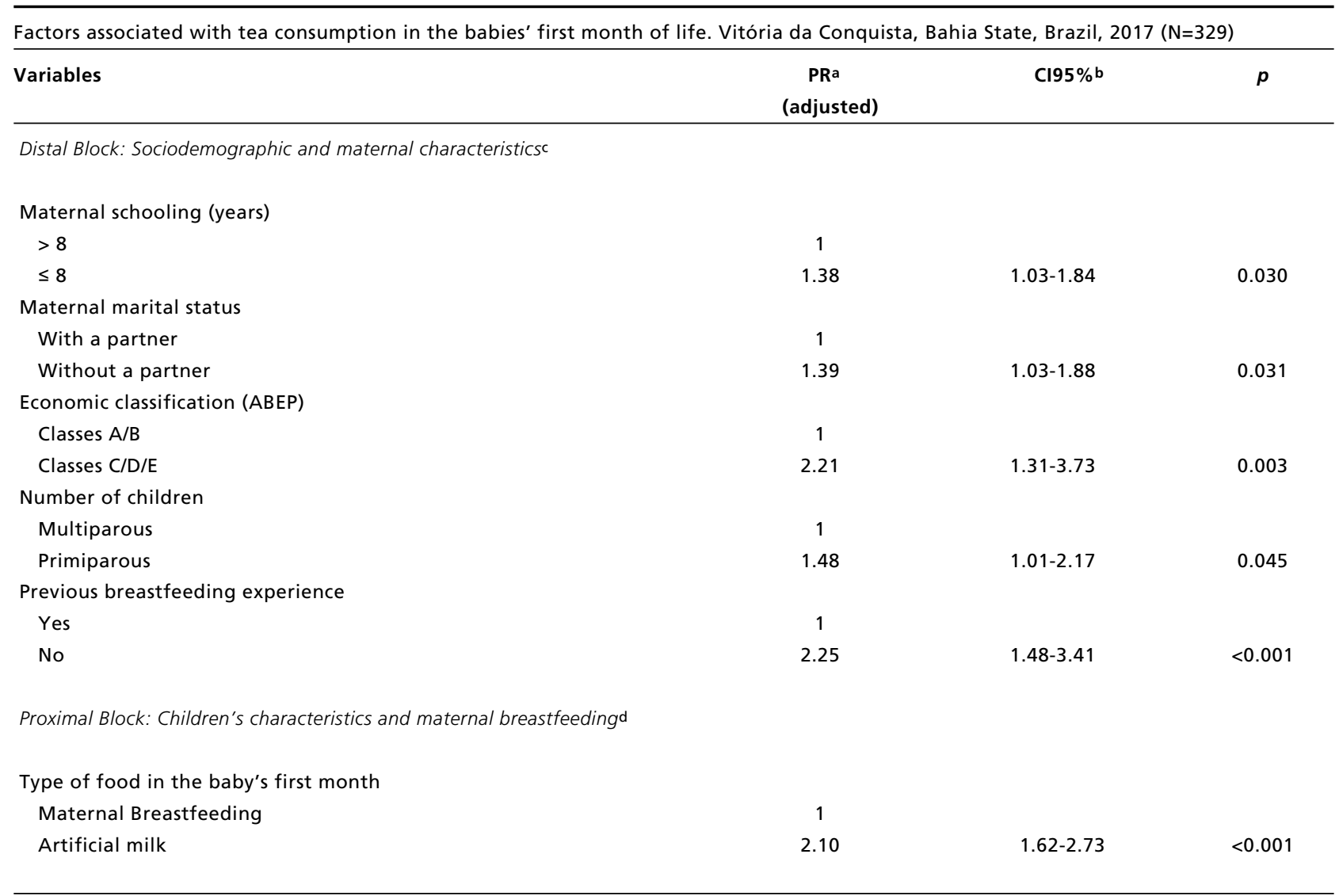

a $\mathrm{PR}=$ prevalence ratio; b $\mathrm{Cl} 95 \%=95 \%$ confidence interval; c Adjusted between sociodemographic and maternal variables (distal block); dAdjusted between sociodemographic and maternal variables (distal block) and variables associated with children and maternal breastfeeding (proximal block); ABEP = Associação Brasileira de Empresa de Pesquisa (Brazilian Association of Research). 
treating cold, and hydrating children. ${ }^{20}$ On the other hand, based on a study conducted with American mothers, the main reasons to give tea to babies was to calm them, help on the digestion processes and treating colic. 21

Sociodemographic factors such as low schooling and income level were associated with the introduction of tea in the children's first month of life in the present study. This outcome corroborates the study carried out in five Brazilian macro-regions, ${ }^{1}$ which has shown association between low maternal schooling and giving tea to babies in their first 30 days of life. Several national and international studies have found association between economic indicators and early introduction of fluids and other types of food.3,4,22 Such an early introduction may be associated with women's lower access to information about healthy eating practices and with their slight difficulty in reading and understanding educational materials provided by the health services. ${ }^{23}$ It was also suggested that the lack of knowledge in association with low socioeconomic level, makes several mothers see teas as natural remedies; consequently, they attribute important functions to them, such as mitigating infantile colic and gas.

The early introduction of fluids and/or solid food in babies' diet can lead to shorter breastfeeding time, affect the absorption of breast milk nutrients, as well as increase the likelihood of contamination and allergic reactions. 24

Mothers who did not have previous breastfeeding experience gave higher amount of tea to their babies in their first 30 days of life. A study carried out at Unidades Básicas de Saúde (UBS), (Basic Health Units) in Rio de Janeiro City has shown that women who did not have experience in the breastfeeding process were $57 \%$ more likely to introduce fluids in their children's diet. 13

Mothers who did not breastfeed their previous children tend to follow instructions provided by family members such as children's grandmothers, who advise them to give water and/or tea to their babies in their first month of life, because they believe it is the most appropriate thing to do at this stage.2,12 These grandmothers had their children between the 1960s and 1980s, when the beneficial properties of breastfeeding were not so well evidenced in the scientific literature yet. Thus, beliefs about "weak milk" prevailed even among pediatricians, and it resulted in the spread of their experiences. 25

Such a family culture passed on from generation to generation has an even more important impact on primiparous women, 26 who deal with insecurities and uncertainties about the breastfeeding process and about the time to introduce fluids in children's diet. 18

In the current study, mothers without a partner introduced tea in their newborns' diet more often. These women live with less emotional, social and economic support from a partner, which is often counterbalanced by the support of a family member such as maternal grandmothers. ${ }^{13}$

Artificial milk in the children's first month of life was associated with higher prevalence of tea introduction in children's diet. It is possible to suggest that this association may be linked to likely increased incidence of intestinal colic in children consuming artificial milk in their first thirty days of life, which may have led to increase tea consumption. A cohort study conducted in the South of Brazil has shown that breastfeeding was the main protective factor against colic development. 27

The aim of this present study was to investigate factors associated with early tea introduction in children's diet in their first month of life. Despite the high prevalence of tea consumption among newborns in the country, 4,6,18,19,28 studies available in the literature about factors exclusively associated with tea consumption remain scarce and are old.3,12 This fact emphasizes the importance of this current study.

The cross-sectional approach of the current study can be mentioned as a limiting factor, since exposure and outcome are analyzed concurrently, and it makes it difficult to establish the temporal between possible predictors and the dependent variable (temporality bias). However, the interviews were carried out at the children's $30^{\text {th }}$ day of life; thus, the addressed experience are in the near past, which reduced the likelihood of memory and temporality bias. The question about tea was only referred to whether or not it was given to the babies; thus, it was not possible to classify the types of tea and the consumed volume. Since the rural population was not investigated, results can be extrapolated to urban groups who present similar characteristics to these studied population.

Results in the current study point toward the inadequate practice of giving tea to babies in their first 30 days of life, a fact that deserves attention from the health professionals due to the significant impacts tea consumption can have on immature bodies, among those are: dehydration, electrolyte disturbances and toxicity, 29 which are factors capable of increasing the risk of morbidity and 
mortality in this population.

In addition, artificial milk was associated with tea consumption in the babies' first month of life, and it can compromise their nutritional status, or unless, in case of duly justified prescription, such a practice is unnecessary and even harmful to children's health.

It is of paramount importance of taking health education actions in prenatal and postpartum consultations mainly focused on women presenting low economic level, low schooling, primiparous women and women who do not have a partner. This population must be instructed about the harm tea can bring to children's health and about the damage caused by this practice in breastfeeding, so they can feel safe and encouraged to perform exclusive breastfeeding until the sixth month of their babies' lives.

\section{Authors' contribution}

Cirqueira RP, Novaes TG and Gomes AT contributed in the analysis, data interpretation and manuscript writing. Bezerra VM, Netto MP and Rocha DS contributed conception, study designed and critical revision of manuscript. All authors approved the final version of the article.

\section{References}

1. Saldiva SRDM, Venancio SI, Gouveia AGC, Castro ALS, Escuder MML, Giugliani ERJ. Influência regional no consumo precoce de alimentos diferentes do leite materno em menores de seis meses residentes nas capitais brasileiras e Distrito Federal. Cad Saúde Pública. 2011; 27 (11): 2253 62.

2. Ferreira TDM, Piccioni LD, Queiroz PHB, Silva EM, Vale IN. Influência das avós no aleitamento materno exclusivo: estudo descritivo transversal. Einstein (São Paulo). 2018; 16 (4): $1-7$.

3. Venancio SI, Saldiva SRDM, Mondini L, Levy RB, Escuder MML. Early Interruption of Exclusive Breastfeeding and Associated Factors, State of São Paulo, Brazil. J Human Lactation. 2008; 24 (2): 168-74.

4. Schneider B, Gatica-Domínguez G, Assunção M, Matijasevich A, Barros A, Santos I, Silveira M. Introduction to complementary feeding in the first year of life and risk of overweight at 24 months of age: Changes from 2004 to 2015 Pelotas (Brazil) Birth Cohorts. Br J Nutr. 2020; 124 (6): 620-30.

5. Gasparin VA, Strada JKR, Moraes BA, Betti T, Pitilin EB, Espírito Santo LC. Fatores associados à manutenção do aleitamento materno exclusivo no pós-parto tardio. Rev Gaúcha Enferm. 2020; 41 (esp): 1-8.

6. Brasil. Ministério da Saúde. II Pesquisa de Prevalência do Aleitamento Materno nas Capitais Brasileiras e Distrito Federal. Ministério da Saúde, Secretaria de Atenção à Saúde, Departamento de Ações Programáticas e Estratégicas. Brasília, DF; 2009.

7. Gonçalves VSS, Silva SA, Andrade RCS, Spaniol AM, Nilson EAF, Moura IF. Marcadores de consumo alimentar e baixo peso em crianças menores de 6 meses acompanhadas no Sistema de Vigilância Alimentar e Nutricional, Brasil, 2015. Epidemiol Serv Saúde. 2019; 28 ( 2 ): 1-11.

8. Manteiga R, Park DL, Ali SS. Risks associated with consumption of herbal teas. Rev Environ Contam Toxicol. 1997; 150: 1-30
9. PAHO/WHO, Guiding Principles for Complementary Feeding of the Breastfed Child. Division of Health Promotion and Protection/Food and Nutrition Program, Washington, DC, USA; 2003.

10. Euclydes MP. Nutrição do lactente: base científica para uma alimentação adequada. Viçosa: Universidade Federal de Viçosa; 2014

11. Machado AKF, Elert VW, Pretto ADB, Pastore CA. Intenção de amamentar e de introdução de alimentação complementar de puérperas de um Hospital-Escola do sul do Brasil. Ciênc Saúde Coletiva. 2014; 19 (7): 1983-9.

12. Giugliani ER, Espírito Santo LC, Oliveira LD, Aerts D. Intake of water, herbal teas and non-breast milks during the first month of life: Associated factors and impact on breastfeeding duration. Early Human Dev. 2008; 84: 305-10.

13. Niquini RP, Bittencourt SA, Lacerda EMA, Oliveira MIC, Leal MC. Acolhimento e características maternas associados à oferta de líquidos a lactentes. Revista de Saúde Pública. 2010; 44 (4): 677-85.

14. Campos MAS, Chaoul CO, Carmona EV, Higa R, Vale IN. Prática de aleitamento materno exclusivo informado pela mãe e oferta de líquidos aos seus filhos. Rev Latino-Am Enf. 2015; 23 (2): 283-90.

15. Wojcicki JM, Holbrook J, Lustig RH, Caughey AB, Muñoz RF, Heyman MB. Infant Formula, Tea, and Water Supplementation of Latino Infants at 4-6 Weeks Postpartum. Hum Lact. 2011; 27 (2): 122-30.

16. IBGE (Instituto Brasileiro de Geografia e Estatística). Cidades e Estados [Internet]. Rio de Janeiro: Instituto Brasileiro de Geografia e Estatística; 2020. Disponível em: https://cidades.ibge.gov.br/brasil/ba/vitoria-daconquista/panoramaba/vitoria-da-conquista.html

17. ABEP (Associação Brasileira de Estudos Populacionais). Critério de Classificação Econômica Brasil. 2014. [acesso abr 2017]. Disponível em: <www.abep.org>

18. Schincaglia RM, Oliveira AC, Sousa LM, Martins KA. Práticas alimentares e fatores associados à introdução 
precoce da alimentação complementar entre crianças menores de seis meses na região noroeste de Goiânia Epidemiol Serv Saúde. 2015; 24 (3): 465-74.

19. Fonseca PCA, Carvalho CA, Ribeiro SAV, Nobre LN, Pessoa MC, Ribeiro AQ, Priore SE, Franceschini SCC Determinantes da velocidade média de crescimento de crianças até seis meses de vida: um estudo de coorte. Ciênc Saúde Coletiva. 2017; 22 (8): 2713-26.

20. Marques ES, Cotta RMM, Priore SE. Mitos e crenças sobre o aleitamento materno. Ciênc Saúde Coletiva. 2011; 16 (5): 2461-8.

21. Zhang Y, Fein EB, Fein SB. Feeding of Dietary Botanical Supplements and Teas to Infants in the United States. Pediatrics. 2011; 127 (6): 1060-66.

22. Wang L, Grieken AV, Velde LAVD, Vlasblom E, Beltman M, L'Hoir MP, Boere-Boonekamp MM, Raat H. Factors associated with early introduction of complementary feeding and consumption of non-recommended foods among Dutch infants: the BeeBOFT study. BMC Public Health. 2019; 19: 388.

23. Dallazen C, Silva SA, Gonçalves VSS, Nilson EAF, Crispim SP, Lang RMF, Moreira JD, Tietzmann DC, Vítolo MR. Introdução de alimentos não recomendados no primeiro ano de vida e fatores associados em crianças de baixo nível socioeconômico. Cad Saúde Pública. 2018; 34 (2): e00202816.
24. Brasil. Ministério da Saúde. Secretaria de Atenção Primária à Saúde. Departamento de Promoção da Saúde. Guia alimentar para crianças brasileiras menores de 2 anos. Brasília, DF; 2019. 265p.

25. França MCT, Giugliani ERJ, Oliveira LD, Weigert EML, Espirito Santo LC, Köhler CV, Bonilha ALL. Uso de mamadeira no primeiro mês de vida: determinantes e influência na técnica de amamentação. Rev Saúde Pública. 2008; 42 (4): 607-14.

26. Gross FM, Van der Sand ICP, Girardon-Perlini NMO, Cabral FB. Influência das avós na alimentação de lactentes: o que dizem suas filhas e noras. Acta Paul Enferm. 2011; 24 (4): 534-40.

27. Saavedra MAL, Costa JSD, Garcias G, Horta BLH, Tomasi E, Mendonça R. Incidência de cólica no lactente e fatores associados: um estudo de coorte. J Pediatr. 2003; 79 (2) $115-22$.

28. Mosquera PS, Lourenço BH, Gimeno SGA, Malta MB, Castro MC, Cardoso MA. Factors affecting exclusive breastfeeding in the first month of life among Amazonian children. PLoS One. 2019; 14 (7): e0219801.

29. Woolf AD. Herbal Remedies and Children: Do They Work? Are They Harmful? Pediatrics. 2003; 112 (1): 240-46.
Received on September 2, 2019

Final version presented on September 20, 2020

Approved on September 29, 2020 